Research article

\title{
Effect of Henna Addition on the Surface Roughness and Hardness of Polymethylmethacrylate Denture Base Material: An In-vitro Study
}

\author{
Amal Nawasrah', Mohammad Gad², Mai El Zayat ${ }^{3}$
}

1 Department of Substitutive Dental Sciences, College of Dentistry, University of Dammam, P.O. Box 1982, Dammam 31411, Saudi Arabia

2 Department of Substitutive Dental Sciences, College of Dentistry, University of Dammam, P.O. Box 1982, Dammam 31411, Saudi Arabia email: mmjad@uod.edu.sa

3 Department of Substitutive Dental Sciences, College of Dentistry, University of Dammam, P.O.

Box 1982, Dammam 31411, Saudi Arabia email: mmelzayat@uod.edu.sa

Corresponding author: Amal Mahmoud Nawasrah, E-mail: amnawasrah12345@gmail.com, amnawasrah@uod.edu.sa

\section{ABSTRACT}

Statement of problem: Henna has been added to polymethylmethacrylate (PMMA) as a new type of antifungal agent; however, its effect on the latter's physical properties has not been investigated.

Purpose: This study aimed to evaluate the effect of the addition of various henna concentrations on the surface roughness and hardness of PMMA denture base material.

Materials and Methods: A total of 99 specimens of rectangular-shaped $\left(10 \times 20 \times 3 \mathrm{~mm}^{3}\right)$ acrylic specimens were prepared from heat-cured acrylic resin. Specimens were divided into one control group without the addition of henna and five test groups, which were prepared by adding Yamani henna powder to acrylic powder at concentrations of $1 \mathrm{wt} \%, 2.5 \mathrm{wt} \%$, $5 \mathrm{wt} \%, 7.5 \mathrm{wt} \%$, and $10 \mathrm{wt} \%$. The polymer was added to the monomer before being mixed, packed, and processed using the conventional water bath method. After processing, specimens were finished and polished, then kept in distilled water for $48 \pm 2 \mathrm{~h}$. A profilometer and Vickers hardness tester were used to measure surface roughness and hardness respectively. Statistical data analysis was conducted via SPSS version 20.0 (IBM, USA).

Results: The addition of henna at varying concentrations significantly increased surface roughness values $(P \leq 0.01)$ while decreasing hardness $(P \leq 0.0001)$. The most favorable addition value was $1 \%$ henna between all henna groups.

Conclusion: The addition of henna to the acrylic resin may negatively affect the surface properties of PMMA acrylic denture base.

Keywords: Polymethylmethacrylate PMMA, Henna, Physical properties, Hardness, Surface roughness 


\section{Introduction:}

Denture stomatitis (DS) is an inflammation of the mucosa under the complete denture (Yarborough et al., 2016). A symptomless disease (Walsh et al., 2015), its over- or under-diagnosis will lead to problems such as errors in treatment and abuse of antifungal agents, leading to antimicrobial resistance (Oliver et al., 2004). Instances of DS become more common with increasing age, especially in medico-compromised patients (Ishikawa et al., 2015). Candida albicans is a common organism in the oral cavity (Sardi et al., 2013); known as a pathogenic species, it may cause not only mucosal but also deep-tissue infections that can reach the bloodstream (Filioti et al., 2007). Candida albicans is able to adhere to the surface of polymethylmethacrylate (PMMA) denture base material. The presence of plaque and poor oral hygiene will render the organism virulent (Ishikawa et al., 2015), leading to the development of DS (Paranhos et al., 2007). Its pathogenicity has increased recently due to excessive use of antibiotics and immunosuppressors.

Treatment of DS includes adjusting the existing denture and following oral hygiene instructions. The attainment of an antimicrobial denture is the aim of many researchers and dentists, who have attempted to make certain modifications to PMMA such as treating the denture surface (Yodmongkol et al., 2014) or coating it with hydrophilic material (Yoshijima et al., 2010) to reduce the adherence of microbial agents (Gendreau and Loewy, 2011). The treatment of PMMA resins has been effected through various mechanisms, including the addition of antimicrobial polymer (10\% PTBAEMA) to PMMA to reduce the adhesion and growth of Candida albicans on the denture bases (Compagnoni et al., 2014). Among these agents, henna was added to the denture base as an antifungal agent to prevent DS (Nawasrah et al., 2016).

Henna is a naturally occurring plant that is mainly used for coloring the hair and hands (Yusuf et al., 2012). In a recent review of the pharmacological effect of henna, it was found that it has antiinflammatory, antimicrobial, and antioxidant properties (Chaudhary et al., 2010; Singla et al., 2013; Saadabi, 2007). In addition, henna has burn wound healing properties (Muhammad and Muhammad, 2005) and even antitumor effects (Jha et al., 2009).

The characteristics of surface roughness affect the adhesion and initial biofilm formation of Candida albicans on acrylic surfaces, most likely because PMMA provides a greater surface area and protected sites for colonization (Lamfon et al., 2003). Some studies have shown a direct correlation between surface roughness and Candida albicans; both plaque accumulation and said organism's adhesion was enhanced when surface roughness increased (Radford et al., 1997).

Hardness is defined as the resistance of a material to permanent surface indentation or penetration; it is considered an indicator of the denture base material's abrasiveness. The surface properties of PMMA denture base material can be affected by hardness, which is characteristic of the ease of finishing the material as it is resistant to in-service scratching during cleansing (De Rezende Pinto et al., 2010). 
Although the addition of henna to PMMA has antimicrobial advantages, the surface properties of PMMA denture base material after such addition have not been investigated. Therefore, the aim of this study was to evaluate the effect of henna incorporation in PMMA on the latter's surface roughness and hardness properties. The hypothesis is that the addition of henna to a PMMA denture base will affect the latter's surface properties.

\section{Materials and methods}

A power analysis of sample size revealed that a total of 99 specimens $(n=9)$ was required. This study involved an in-vitro investigation of 99 specimens of rectangular-shaped $\left(10 \times 20 \times 3 \mathrm{~mm}^{3}\right)$ acrylic plates, prepared using heat-cured acrylic resin (Major base 20, Major Prodotti Dentari SPA, Italy) and divided into two main groups with different ratio calculation, each group will be divided into six subgroups $(n=9)$, Group 1 specimens' powder $=A R+$ henna

Group 2 specimens' powder $=$ AR only + henna as additive to which were added Yamani henna powder (Harazi, Sanaa, Yeman) at concentrations of $0 \mathrm{wt} \%, 1 \mathrm{wt} \%, 2.5 \mathrm{wt} \%, 5 \mathrm{wt} \%, 7.5 \mathrm{tw} \%$, and $10 \mathrm{wt} \%$. An electronic balance (Denver instrument $\mathrm{GmbH}$, Goettingen, Germany) was used to weigh the henna, which was then added to the PMMA powder inside bottles and shaken manually for around three minutes each. The first group of 54 specimens was distributed into six subgroups $(\mathrm{n}=9)$ (see Table 1).

Table 1. Ratio of henna to acrylic resin powder in both groups

\begin{tabular}{|c|c|c|c|c|c|c|}
\hline Group & Subgroups & Code & $\begin{array}{l}\text { Polymer } \\
\text { conc. Gm }\end{array}$ & $\begin{array}{l}\text { Henna } \\
\text { conc. } \\
\text { Gm }\end{array}$ & Total & \# \\
\hline Control & $0 \%$ & & 100 & 0 & $100 \mathrm{gm}$ & 9 \\
\hline \multirow{5}{*}{ Group 1} & $1 \%$ & & 99 & 1 & $100 \mathrm{gm}$ & 9 \\
\hline & $2.5 \%$ & & 97.5 & 2.5 & $100 \mathrm{gm}$ & 9 \\
\hline & $5 \%$ & & 95 & 5 & $100 \mathrm{gm}$ & 9 \\
\hline & $7.5 \%$ & & 92.5 & 7.5 & $100 \mathrm{gm}$ & 9 \\
\hline & $10 \%$ & & 90 & 10 & $100 \mathrm{gm}$ & 9 \\
\hline \multirow{5}{*}{ Group 2} & $1 \%$ & & 100 & 1 & $101 \mathrm{gm}$ & 9 \\
\hline & $2.5 \%$ & & 100 & 2.5 & $102.5 \mathrm{gm}$ & 9 \\
\hline & $5 \%$ & & 100 & 5 & $105 \mathrm{gm}$ & 9 \\
\hline & $7.5 \%$ & & 100 & 7.5 & $107.5 \mathrm{gm}$ & 9 \\
\hline & $10 \%$ & & 100 & 10 & $110 \mathrm{gm}$ & 9 \\
\hline
\end{tabular}

Group 1 specimens' powder $=A R+$ henna

Group 2 specimens' powder $=$ AR only + henna as additive

For the first group, the powder was the sum of both the PMMA and henna powder with a powder-liquid ratio of 1:1 (Nawasrah et al., 2016). Meanwhile in the second group, the remaining 45 
specimens were distributed into five subgroups; the control group was the same for both groups ( $\mathrm{n}=$ 9). In the second group, henna was added to the PMMA powder; therefore, the powder consisted completely of PMMA-liquid (1:1). Both groups were used to test the roughness and hardness, using a profilometer and hardness tester respectively.

A silicone mold with internal dimensions of $10 \times 20 \times 3 \mathrm{~mm}^{3}$ was used to fabricate 99 wax specimens (Cavex setup wax, Cavex, Netherland). The wax specimens were invested in dental stone (Talladium dental stone, USA). After dewaxing the randomly allocated flasks (61B Two Flask Compress, Handler Manufacturing, US), the mold spaces were cleaned and a thin separating media was applied (Isolmajor, Major Prodotti Dentari SPA, Italy). The PMMA/henna composites-were mixed with the monomer until a doughy consistency was attained, before being packed into the mold. The specimens were placed in an automatic polymerization water tank (KaVo Elekto Technisches WERK GmbH D-88299 Leutkirch im Allgau, TYP 5506, Germany). Temperature was maintained at $73 \circ \mathrm{C}$ for 90 minutes, before being increased to $100^{\circ} \mathrm{C}$ for 30 minutes. After processing, flasks were left aside for bench cooling for at least five hours before deflasking. The deflasked specimens were finished and polished using the Buehler MetaServ 250 Polisher and Grinder. Specimens were polished with a polishing cloth and a Masterprep Polishing Solution ( 0.05 micron) at speed using water as a cooling agent then stored in distilled water at $37^{\circ} \mathrm{C}$ for $48 \pm 2 \mathrm{~h}$ before testing (Regis et al., 2011).

\section{Testing procedures}

The testing of the surface roughness was performed using the appropriate tester (Contour GT, Bruker Nano gmbH Schwarzschildstrasse 12, 12489 Berlin, Germany). A linear variable differential transformer was deployed to measure the surface morphology, while the numerical values of the surface profile were calculated in a computer to obtain the $\mathrm{Ra}$ (the roughness of a surface, which is the mean value of all absolute distances of the roughness profiles from the mean line within the measuring distance using the noncontact lens during tracing).

The hardness test was conducted using the corresponding tester (Wilson Hardness, ITW Test \& Measurement GmbH, Shanghai, China) equipped with a Vickers diamond. Eight indentations were made per specimen through the application of a 25 -gf load for 30 seconds. To attain the final hardness values, the average of the eight indentations was calculated for each specimen (Regis et al., 2011).

\section{Statistical analysis}

Statistical data analysis was performed using SPSS version 20.0 (IBM, USA). The results of the surface roughness and hardness tests were shown as arithmetic mean and standard deviation (SD). For intragroup comparisons with the control group, an independent sample t-test used. A $P$-value $\leq$ 0.05 was considered a statistically significant result. 


\section{Results}

The mean values and SD of the Ra are summarized in Table 2; it can be observed that the henna powder significantly increased in Ra value for all concentrations in both groups $(P$-value $\leq 0.01)$, in comparison to the control group. The addition of $1 \%$ powder returned the lowest Ra value $(0.0501 \pm$ $.0052)$ under the micrometer, while the $10 \%$ addition resulted in the highest value $(0.316 .9 \pm .0351)$. As the henna concentration increased, the hardness decreased

Among the groups, there were significant differences between those with $1 \%$ and $7.5 \%$, while there were no significant differences between other groups. Figures 2 and 3 show the average surface roughness values using parameters with two colors (red and blue). Red denotes the peak's height, while blue reflects the valley's depth, or deviation, from a mean line. The graduated colors between red and blue (the readings for the top and bottom) in this parameter represent the overall surface roughness.

Table 3 shows the mean values and SD of the hardness test. Statistical analysis revealed that the hardness reduced significantly $(P$-value $\leq 0.0001)$ in comparison to the control group, as well as between groups.

Table 2. Main values and standard deviation of surface roughness $(\mu \mathrm{m})$ results

Group 1

$$
\text { Mean (SD) P-value }
$$

Mean (SD)

Group 2

\begin{tabular}{|c|c|c|c|c|c|}
\hline & Mean (SD) & P-value & Mean (SD) & P-value & $\begin{array}{c}\text { Comparison } \mathbf{b} / \mathbf{v} \\
\text { groups }\end{array}$ \\
\hline $0 \%$ & \multicolumn{2}{|l|}{$0.01738+.0016$} & \multicolumn{2}{|l|}{$0.01738+.0016$} & \\
\hline $1 \%$ & $0.0501 \pm .0052$ & $0.0001^{*}$ & $0.0398+0.0021$ & $0.0001^{*}$ & $0.0001^{*}$ \\
\hline $2.5 \%$ & $0.0556 \pm .0069$ & $0.0001^{*}$ & $0.0552 \pm 0.0059$ & $0.0001^{*}$ & 0.44 \\
\hline $5 \%$ & $0.1568 \pm .0132$ & $0.0001^{*}$ & $0.1499 \pm 0.0139$ & $0.0001^{*}$ & 0.089 \\
\hline $7.5 \%$ & $0.2436 \pm .0343$ & $0.0001^{*}$ & $0.2778 \pm 0.0337$ & $0.0001^{*}$ & $0.0058^{*}$ \\
\hline $10 \%$ & $0.316 .9 \pm .0351$ & $0.0001^{*}$ & $0.3222 \pm 0.0429$ & $0.0001^{*}$ & 0.36 \\
\hline \multicolumn{6}{|c|}{ *Statistically significant } \\
\hline & \multicolumn{5}{|c|}{ Table 3. Main values and standard deviations of hardness $\left(\mathrm{Kg} / \mathrm{mm}^{2}\right)$ results } \\
\hline & \multicolumn{2}{|c|}{ Group 1} & \multicolumn{2}{|l|}{ Group 2} & Mean \\
\hline & Mean \pm SD & P-value & Mean \pm SD & P-value & $\begin{array}{c}\text { Comparison } b / w \\
\text { groups }\end{array}$ \\
\hline $0 \%$ & $30.1 \pm 0.58$ & & $30.1 \pm 0.58$ & & \\
\hline $1 \%$ & $29.5 \pm 0.77$ & 0.013 & $30.5 \pm 0.39$ & 0.003 & 0.0001 \\
\hline $2.5 \%$ & $29.1 \pm 0.62$ & 0.0001 & $29.6 \pm 0.399$ & 0.0001 & 0.0095 \\
\hline $5 \%$ & $24.1 \pm 0.36$ & 0.0001 & $23.6 \pm 0.38$ & 0.0001 & 0.00093 \\
\hline $7.5 \%$ & $19.9 \pm 0.39$ & 0.0001 & $18.8 \pm 0.33$ & 0.0001 & 0.0001 \\
\hline $10 \%$ & $15.4 \pm 0.2$ & 0.0001 & $15.7 \pm 0.31$ & 0.0001 & 0.0026 \\
\hline
\end{tabular}



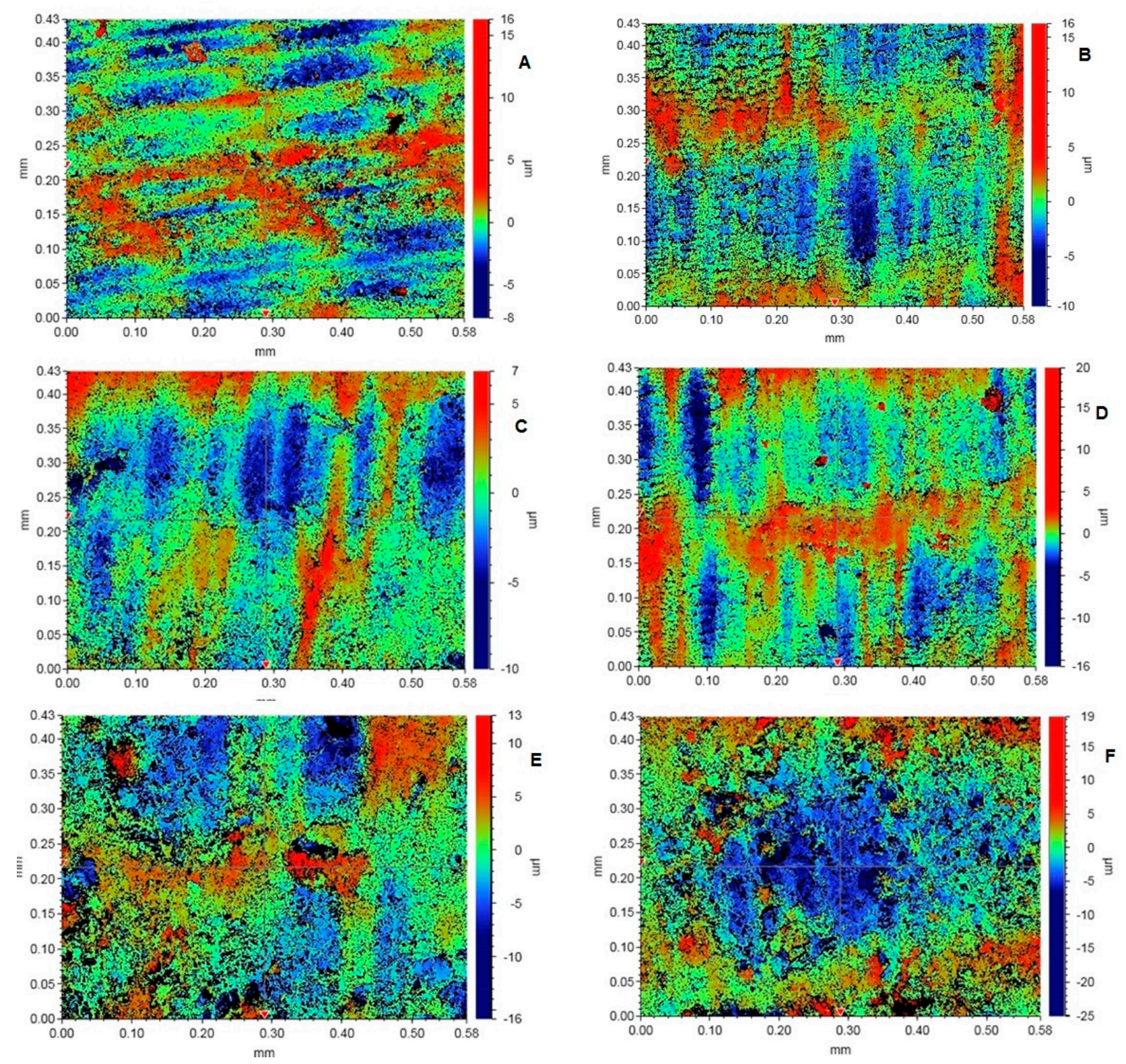

Figure 1. $2 D$ representative surface roughness images of tested specimens according to henna concentrations: A $0 \%$ henna, B 1\% henna, C 2.5\% henna, D 5\% henna, E 7.5\% henna, F 10\% henna 

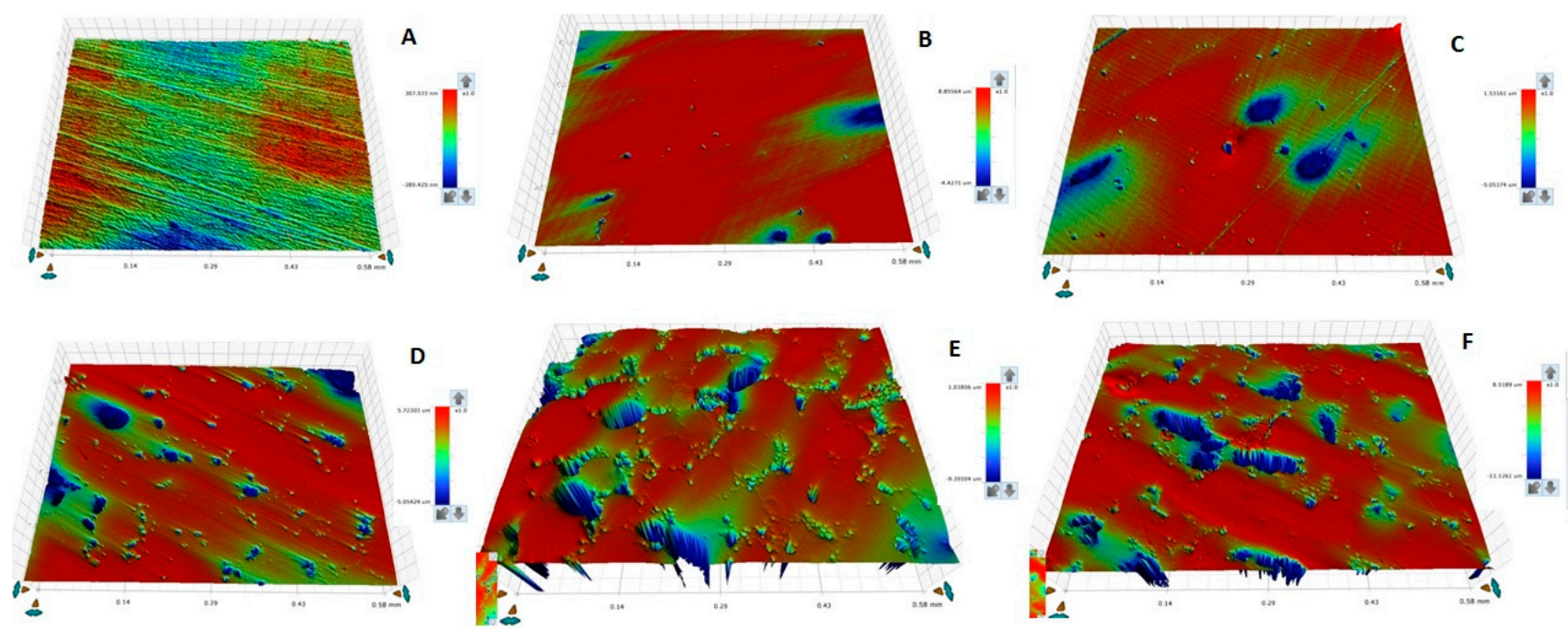

Figure 2. $3 D$ representative surface roughness images of tested specimens according to henna concentrations: A 0\% henna, B 1\% henna, C 2.5\% henna, D 5\% henna, E 7.5\% henna, F 10\% henna

\section{Discussion}

With the aim of improving the oral health of denture wearers, many studies have suggested the addition of antifungal agents to PMMA acrylic resin, which may represent a possible alternative method of controlling oral infections. Although henna powder has an antifungal effect when added to the PMMA denture base material, it may alter the latter's surface characteristics. Accordingly, this invitro study was carried out to evaluate the effect of henna on surface properties, with the results indicating that said properties affected specially with high henna concentrations. Therefore, the hypothesis was accepted.

The surface properties of denture base material are important as they affect the oral health of tissues in direct contact with the dentures. Since the initial adhesion of microorganisms is directly influenced by the surface roughness (Kolenbrander et al., 2002), the latter can increase or decrease microbial adhesion, colonization, and biofilm maturation (Cunha et al., 2009; Zamperini et al., 2010). It has been reported that resins with high Ra values displayed higher numbers of Candida albicans specimens in comparison to highly polished smooth surfaces, possibly due to the increased hills and peaks of the rougher surfaces, which provide a wide surface area and are more accessible active sites for microbial adhesion (Verran and Maryan, 1997; Radford et al., 1998). Lower surface roughness is important to prevent stain catching (Consani et al., 2016).

The results of the current study showed that henna, as an addition to the PMMA denture base material, significantly increased the surface roughness $(\mathrm{Ra})$ of the specimens $(P$-value $\leq 0.01)$. The reduction in $\mathrm{Ra}$ values with high henna concentrations may be attributed to the existing loosely attached clusters of henna particles on the resin surface, which are easily removed using finishing and polishing techniques, leaving voids. 
A removable prosthesis with $0.2 \mu \mathrm{m}$ surface roughness is considered acceptable for clinical use (Arora et al., 2015) and plaque accumulation of more than this value is expected in prosthetics (Bollenl et al., 1997; Arora et al., 2015). This increases the microbial adhesion, which is considered critical in impacting the value of PMMA roughness (Zissis et al., 2000). Ra values found in this study for henna groups of low concentrations $(1 \%, 2.5 \%, 5 \%)$ were below this level and considered clinically acceptable. In contrast, with the increased concentrations of $7.5 \%$ and $10 \%$, the values exceeded the clinically acceptable threshold. Therefore, $5 \%$ henna could be considered as the limit, below which microbial adhesion reduction might be anticipated.

Compagnoni et al. (2014) studied the effect of antimicrobial polymer (poly[2-tertbutylaminoethyl] methacrylate [PTBAEMA]) on the surface roughness and found that the addition of PTBAEMA to a PMMA acrylic denture base increased the Ra values, which is in line with the results of the current study. Meanwhile, Regis et al. (2011) showed that the use of antimicrobial monomer methacryloyloxyundecylpyridinium bromide (MUPB) had no effect on the roughness of polished acrylic resin. Another team used alcohol vinegar in the PMMA as a way to reduce the number and adhesion of Candida albicans specimens; this had no effect on the surface roughness of the PMMA (de Castro et al., 2015). The differences in results may be due to the nature of the added antimicrobial agents, concentrations, methods of additions, or the PMMA denture base material used. Although clear correlations have been reported between surface roughness and microbial adhesion and biofilm formation (Cunha et al., 2009), one group reported no significant influence of roughness on adherence of Candida albincans (Moura et al., 2006). Therefore, whether surface roughness enhances or reduces microbial adhesion remains a matter for debate.

The hardness test has been considered a simple and useful method to determine the mechanical properties of polymer-based materials due to its high sensitivity to the amount of monomer in dental polymers (Azevedo et al., 2005). Hardness is important in preventing abrasion and wearing of the PMMA denture base (Consani et al., 2016).

It was observed that the hardness significantly decreased after the addition of henna at all concentrations. This may imply that the incorporation of henna interferes with the conversion of the tested resin. A possible reason for such an effect is the incomplete polymerization process of PMMA denture base material after the addition of henna, resulting in a large amount of residual monomer. The latter adversely affects the mechanical properties via a plasticizing effect (Faltermeier et al., 2007). In addition, increased henna concentrations that are above the saturation limit act as impurities within the resin matrix, subsequently weakening the materials and affecting their mechanical properties. As we have seen, increasing the henna concentration decreased the hardness of the PMMA resins. This may be explained by the fact that the maximum saturation of the matrix formation between PMMA and henna occurred at concentrations of 1\% and 2.5\% (Aydogan Ayaz et al., 2013).

With the aim of improving the properties of the PMMA denture base, antimicrobial polymers were added. Regis et al. (2011) found that the incorporation of $0.6 \%$ antimicrobial MUPB reduced the base's hardness, in agreement with the results of the current study. That said, our results are in opposition to a study in which alumina was added to the PMMA, which had a positive impact on the 
latter's physical and mechanical properties (Arora et al., 2015). The increase in hardness may have been due to the characteristics of the alumina particles, which possess strong ionic interatomic bonding, giving rise to their desired material features that are not found in henna. In addition, in another study (Kati and Al-Kaabi, 2016) it was found that the addition of oil to PMMA for color matching will increase the hardness significantly.

Recently, nanotechnological products have been incorporated into PMMA to induce antimicrobial properties; their effects on the mechanical properties have been evaluated. For example, Köroğlu et al. (2016) studied the effect of silver nanoparticles' (AgNPs) addition on PMMA's mechanical and thermal characteristics, concluding that the incorporation of AgNPs, which are generally used for antimicrobial efficiency, affected the mechanical properties of the PMMA denture base depending on the concentration of nanoparticles.

In group 1 in our study, henna was added as a part of the acrylic powder ratio, while in group 2 it was an additive over the proposed powder ratio. This was done to evaluate the effect of the addition method on the properties of the final products. Table 2 shows comparative values between groups 1 and 2 and displays a significant difference in Ra values. With low concentrations, values of both groups were close while group 2 showed higher values with increased henna concentrations. This confirms that the additive method, with increased concentrations, affects the polymer-monomer ratio, whereas excess henna particles interfere with the polymerization reaction. Table 3 shows comparative values between groups 1 and 2 and displays a significant difference in hardness values. The results of both groups were in close conjunction, with a slight increase in values for group 1. Based on the results of this study, as regards a comparison between the two groups, group 1 is more conventional and could be used for addition; however, this is still ambiguous and further investigations are required at low concentrations.

\section{Clinical implications}

The production of a denture base with an antimicrobial effect would be a remarkable achievement. At the same time, the physical and mechanical properties should not be unduly altered. Based on the results of this study, the addition of henna at a high concentration adversely affects the base's physical properties, while all values obtained for all properties were lower than what is required in accordance with the ISO: 1567 standard requirements. That said, low concentrations were closely aligned with ISO: 1567 No. 12. The addition of henna to the PMMA denture base material should be done with caution, as it may adversely affect the latter's physical properties. It is necessary to study the minimum inhibitory concentration of henna as an antifungal agent. There are various schools of thought as regards the processing of the PMMA denture base material; one is to make the denture on two layers by adding just enough henna to form the intaglio surface of the palatal part of the denture. Another way of thinking is to evaluate the use of microwave processing instead of the conventional hot water bath technique to improve the physical properties of the henna-augmented PMMA denture base material. 


\section{Limitations of the study}

In clinical terms, the results of this study should be taken with caution, as it was performed in vitro where the oral environment is different (lacking dynamic movements, saliva with prospective $\mathrm{pH}$, and the presence of other microorganism); this may affect the denture base surfaces and Candida albicans adhesion. One limitation was the use of just one type of denture base material (that is, PMMA), as it is the most commonly used type in this field. In addition, we could not achieve our goal of retesting the specimens after a certain time had elapsed, to evaluate the effect of aging on the physical properties of PMMA denture base material containing henna. It is essential to conduct further investigations on henna through coating or attempting to enhance the bonding using the resin matrix. In future, it is also warranted to assess the durability through aging procedures that simulate oral conditions.

\section{Conclusion}

Within the limitations of this study, it could be concluded that:

The addition of henna to PMMA denture base material significantly increases the latter's surface roughness and decreases its hardness. The use of henna as an additive constitutes no significant difference from considering it as part of the PMMA powder. A henna concentration of $1 \%$ showed the best results between the henna groups as regards roughness and hardness values.

\section{Conflict of interests}

The authors declare that there is no conflict of interests regarding the publication of this manuscript.

\section{Acknowledgments}

The authors would like to acknowledge the Deanship of Scientific Research, University of Dammam for providing a research grant for this study (Grant No. 2014176). They would also like to sincerely thank Miss Joan M. Coloma for her assistance in preparing the specimens. Gratitude is also extended to Mr. Lindsey Mateo and Mr. Soban Khan for their assistance with the mechanical testing and statistical analysis respectively. 


\section{$\underline{\text { References }}$}

ARORA, P., SINGH, S. \& ARORA, V. 2015. Effect of Alumina Addition on Properties of Poly-methyl methacrylate-A Comprehensive Review. Int $J$ of Biotech Trends and Tech.

AYDOGAN AYAZ, E., DURKAN, R. \& BAGIS, B. 2013. The effect of acrylamide incorporation on the thermal and physical properties of denture resins. The journal of advanced prosthodontics, 5, 110-117.

AZEVEDO, A., MACHADO, A. L., VERGANI, C. E., GIAMPAOLO, E. T. \& PAVARINA, A. C. 2005. Hardness of denture base and hard chair-side reline acrylic resins. Journal of Applied Oral Science, 13, 291-295.

BOLLENL, C. M., LAMBRECHTS, P. \& QUIRYNEN, M. 1997. Comparison of surface roughness of oral hard materials to the threshold surface roughness for bacterial plaque retention: a review of the literature. Dental Materials, 13, 258-269.

CHAUDHARY, G., GOYAL, S. \& POONIA, P. 2010. Lawsonia inermis Linnaeus: a phytopharmacological review. Int J Pharm Sci Drug Res, 2, 91-8.

COMPAGNONI, M. A., PERO, A. C., RAMOS, S. M., MARRA, J., PALEARI, A. G. \& RODRIGUEZ, L. S. 2014. Antimicrobial activity and surface properties of an acrylic resin containing a biocide polymer. Gerodontology, 31, 220-226.

CONSANI, R. L. X., FOLLI, B. L., NOGUEIRA, M. C., CORRER, A. B. \& MESQUITA, M. F. 2016. Effect of Polymerization Cycles on Gloss, Roughness, Hardness and Impact Strength of Acrylic Resins. Brazilian dental journal, 27, 176-180.

CUNHA, T. R., REGIS, R. R., BONATTI, M. R. \& SOUZA, R. F. D. 2009. Influence of incorporation of fluoroalkyl methacrylates on roughness and flexural strength of a denture base acrylic resin. Journal of Applied Oral Science, 17, 103-107.

DE REZENDE PINTO, L., RODRIGUEZ ACOSTA, E. J. T., TÁVORA, F. F. F., DA SILVA, P. M. B. \& PORTO, V. C. 2010. Effect of repeated cycles of chemical disinfection on the roughness and hardness of hard reline acrylic resins. Gerodontology, 27, 147-153.

FALTERMEIER, A., ROSENTRITT, M. \& MÜSSIG, D. 2007. Acrylic removable appliances: comparative evaluation of different postpolymerization methods. American Journal of Orthodontics and Dentofacial Orthopedics, 131, 301. e16-301. e22.

GENDREAU, L. \& LOEWY, Z. G. 2011. Epidemiology and etiology of denture stomatitis. J Prosthodont, 20, 251-60.

ISHIKAWA, K. H., MAYER, M. P. A., MIYAZIMA, T. Y., MATSUBARA, V. H., SILVA, E. G., PAULA, C. R., CAMPOS, T. T. \& NAKAMAE, A. E. M. 2015. A Multispecies Probiotic Reduces Oral Candida Colonization in Denture Wearers. Journal of Prosthodontics, 24, 194-199.

JHA, R. K., JHA, P. K., RANA, S. V. \& GUHA, S. K. 2009. Spermicidal action of styrene maleic anhydride polyelectrolyte in combination with magnetic and electrically conductive particles. Int J Pharmacol, 5, $1-12$.

KATI, F. A. \& AL-KAABI, A. F. J. 2016. Effect of Oil Paint Addition on Micro Hardness of Acrylic Ocular Prosthesis. Iraqi Dental Journal, 38, 87-89. 
KHAN, M., LEHMANN, D., HEINRICH, G., GOHS, U. \& FRANKE, R. 2009. Structure-property effects on mechanical, friction and wear properties of electron modified PTFE filled EPDM composite. Express Polymer Letters, 266, 39-48.

KOLENBRANDER, P. E., ANDERSEN, R. N., BLEHERT, D. S., EGLAND, P. G., FOSTER, J. S. \& PALMER, R. J. 2002. Communication among oral bacteria. Microbiology and molecular biology reviews, 66, 486-505.

KÖROĞLU, A., ŞAHIN, O., KÜRKÇÜOĞLU, I., DEDE, D. Ö., ÖZDEMIR, T. \& HAZER, B. 2016. Silver nanoparticle incorporation effect on mechanical and thermal properties of denture base acrylic resins. Journal of Applied Oral Science, 24, 590-596.

LAMFON, H., PORTER, S. R., MCCULLOUGH, M. \& PRATTEN, J. 2003. Formation of Candida albicans biofilms on non-shedding oral surfaces. European journal of oral sciences, 111, 465-471.

MOURA, J. S., DA SILVA, W. J., PEREIRA, T., CURY, A. A. D. B. \& GARCIA, R. C. M. R. 2006. Influence of acrylic resin polymerization methods and saliva on the adherence of four Candida species. The Journal of prosthetic dentistry, 96, 205-211.

MUHAMMAD, H. \& MUHAMMAD, S. 2005. The use of Lawsonia inermis Linn.(henna) in the management of burn wound infections. African Journal of Biotechnology, 4.

NAWASRAH, A., ALNIMR, A. \& ALI, A. A. 2016. Antifungal Effect of Henna against Candida albicans Adhered to Acrylic Resin as a Possible Method for Prevention of Denture Stomatitis. International journal of environmental research and public health, 13, 520.

PARANHOS, H., SILVA-LOVATO, C., SOUZA, R., CRUZ, P., FREITAS, K. \& PERACINI, A. 2007. Effects of mechanical and chemical methods on denture biofilm accumulation. Journal of oral rehabilitation, $34,606-612$.

RADFORD, D. R., SWEET, S., CHALLACOMBE, S. \& WALTER, J. 1998. Adherence of Candida albicans to denture-base materials with different surface finishes. Journal of dentistry, 26, 577-583.

RADFORD, D. R., WATSON, T. F., WALTER, J. D. \& CHALLACOMBE, S. J. 1997. The effects of surface machining on heat cured acrylic resin and two soft denture base materials: a scanning electron microscope and confocal microscope evaluation. The Journal of prosthetic dentistry, 78, 200-208.

REGIS, R. R., ZANINI, A. P., DELla VECCHIA, M. P., SILVA-LOVATO, C. H., PARANHOS, O., FREITAS, H. \& DE SOUZA, R. F. 2011. Physical properties of an acrylic resin after incorporation of an antimicrobial monomer. Journal of Prosthodontics, 20, 372-379.

SAADABI, M. A. A. 2007. Evaluation of Lawsonia inermis Linn. (Sudanese Henna) Leaf Extarcts as an Antimicrobial Agent. Research Journal of Biological Sciences, 2, 419-423.

SARDI, J., SCORZONI, L., BERNARDI, T., FUSCO-ALMEIDA, A. \& GIANNINI, M. M. 2013. Candida species: current epidemiology, pathogenicity, biofilm formation, natural antifungal products and new therapeutic options. Journal of medical microbiology, 62, 10-24.

SINGLA, S., GUPTA, R., PURI, A., BHARDAWAJ, V. S. \& ROY, S. 2013. Comparison of anticandidal activity of Punica granatum (Pomegranate) and Lawsonia inermis (Henna leaves): An in-vitro study. International Journal of Dental Research, 1, 8-13.

SIVAKUMAR, I., ARUNACHALAM, K. S., SAJJAN, S., RAMARAJU, A. V., RAO, B. \& KAMARAJ, B. 2014. Incorporation of antimicrobial macromolecules in acrylic denture base resins: a research composition and update. J Prosthodont, 23, 284-90. 
SODAGAR, A., BAHADOR, A., KHALIL, S., SHAHROUDI, A. S. \& KASSAEE, M. Z. 2013. The effect of $\mathrm{TiO} 2$ and $\mathrm{SiO} 2$ nanoparticles on flexural strength of poly (methyl methacrylate) acrylic resins. Journal of prosthodontic research, 57, 15-19.

VERRAN, J. \& MARYAN, C. J. 1997. Retention of Candida albicans on acrylic resin and silicone of different surface topography. The Journal of prosthetic dentistry, 77, 535-539.

WALSH, T., RILEY, P. \& VEITZ-KEENAN, A. 2015. Interventions for managing denture stomatitis. The Cochrane Library.

YARBOROUGH, A., COOPER, L., DUQUM, I., MENDONÇA, G., MCGRAW, K. \& STONER, L. 2016. Evidence Regarding the Treatment of Denture Stomatitis. Journal of Prosthodontics.

YODMONGKOL, S., CHANTARACHINDAWONG, R., THAWEBOON, S., THAWEBOON, B., AMORNSAKCHAI, T. \& SRIKHIRIN, T. 2014. The effects of silane-SiO 2 nanocomposite films on Candida albicans adhesion and the surface and physical properties of acrylic resin denture base material. The Journal of prosthetic dentistry, 112, 1530-1538.

YOSHIJIMA, Y., MURAKAMI, K., KAYAMA, S., LIU, D., HIROTA, K., ICHIKAWA, T. \& MIYAKE, Y. 2010. Effect of substrate surface hydrophobicity on the adherence of yeast and hyphal Candida. Mycoses, 53, 221-6.

YUSUF, M., AHMAD, A., SHAHID, M., KHAN, M. I., KHAN, S. A., MANZOOR, N. \& MOHAMMAD, F. 2012. Assessment of colorimetric, antibacterial and antifungal properties of woollen yarn dyed with the extract of the leaves of henna (Lawsonia inermis). Journal of Cleaner Production, 27, 42-50.

ZAMPERINI, C. A., MACHADO, A. L., VERGANI, C. E., PAVARINA, A. C., GIAMPAOLO, E. T. \& DA CRUZ, N. C. 2010. Adherence in vitro of Candida albicans to plasma treated acrylic resin. Effect of plasma parameters, surface roughness and salivary pellicle. Archives of oral biology, 55, 763-770.

ZISSIS, A. J., POLYZOIS, G. L., YANNIKAKIS, S. A. \& HARRISON, A. 2000. Roughness of denture materials: a comparative study. International Journal of Prosthodontics, 13. 